\title{
The People's Network
}




\title{
AMERICAN BUSINESS, POLITICS, AND SOCIETY
}

\author{
Series editors \\ Andrew Wender Cohen, Richard R. John, \\ Pamela Walker Laird, Mark H. Rose, \\ and Elizabeth Tandy Shermer
}

Books in the series American Business, Politics, and Society explore the relationships over time between governmental institutions and the creation and performance of markets, firms, and industries large and small. The central theme of this series is that politics, law, and public policy—understood broadly to embrace not only lawmaking but also the structuring presence of governmental institutions-has been fundamental to the evolution of American business from the colonial era to the present. The series aims to explore, in particular, developments that have enduring consequences.

A complete list of books in the series is available from the publisher. 


\title{
The People’s Network
}

\author{
The Political Economy \\ of the Telephone in the Gilded Age
}

Robert MacDougall

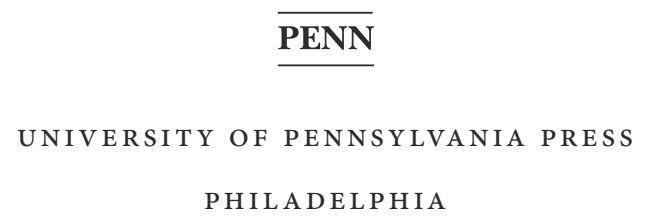




\title{
Copyright (C) 2014 University of Pennsylvania Press
}

All rights reserved.

Except for brief quotations used for purposes of review or scholarly citation, none of this book may be reproduced in any form by any means without written permission from the publisher.

\author{
Published by \\ University of Pennsylvania Press \\ Philadelphia, Pennsylvania 19104-4112 \\ www.upenn.edu/pennpress
}

Printed in the United States of America on acid-free paper 109877654321

\section{Library of Congress Cataloging-in-Publication Data}

MacDougall, Robert.

The people's network : the political economy of the telephone in the Gilded Age / Robert MacDougall._-1st ed.

p. cm.-(American business, politics, and society)

Includes bibliographical references and index.

ISBN 978-0-8122-4569-1 (hardcover : alk. paper)

1. Telephone-United States-History-2oth century.

2. Telephone-Canada-History-2oth century. 3. Telephone companies-United States-History_-2oth century. 4. Telephone companies-Canada-History-2oth century. 5. TelephoneGovernment policy-United States-History—2oth century.

6. Telephone-Government policy-Canada-History—2oth century. 7. American Telephone and Telegraph Company-History. 8. Bell Canada-History. I. Title. II. Series: American business, politics, and society.

TK6023.M25 2013

384.60973' $09041-\mathrm{dc} 23$ 
This story should appeal especially to those who have good red American blood in their veins. It is the story of a magnificent fight that was won against overwhelming odds. It is the story of a smug coterie of "Boston gentlemen" of the immaculate type, put to flight by a few sturdy men out of the West. It is the story of a low, scheming campaign of greed that was turned into a rout by a fine, sentimental, American citizenship. ... It is the story of at least one trust that was "busted." It is a story that, while dealing with the details of an industrial war, will interest even the women, for it is full of good, clean, honest fighting, of the deeds of men who stood shoulder to shoulder under the Stars and Stripes, and, in the name of American freedom and independence, lined up against the most complete and relentless, and successful monopoly of the times-and beat it to a pulp. 
This page intentionally left blank 